\title{
Conversion of Solid Waste-to-Energy (WtE) in Thailand
}

\author{
Siriporn Boonpa ${ }^{*}$ and Alice Sharp \\ The School of Bio-Chemical Engineering and Technology, Sirindhorn International Institute of Technology, Thammasat \\ University, PO Box 22 TU-Rangsit Post Office, Pathum Thani, 12121, Thailand. \\ ${ }^{*}$ Corresponding author
}

\begin{abstract}
In order to increase the efficiency in municipal solid waste management (MSWM), waste-to-energy (WtE) technologies are provided as a solution towards the successful policy in Thailand. WtE is perceived as a means to dispose MSW, produce energy, recover materials, and free up scarce land that would otherwise have been used for landfill. Thailand considers WtE to be a renewable technology, incineration, refuse derived fuel (RDF), anaerobic digestion, pyrolysis and gasification, and landfill gas recovery. These lists are a number of technologies for energy recovery from urban and industrial wastes that "not only reduce the quantity but also improve the quality of waste to meet the required pollution control standards, besides generating a substantial quantity of energy". While the WtE technologies would be suggested that the cost of $\mathrm{WtE}$ is somewhat higher than other renewable sources, it should be kept in mind that WtE facilities serve a dual role of waste disposal and energy production. Although the cost per MW of capacity may be greater than other renewable sources, the benefits of waste management, energy and metals recovery, and reduction of GHG emission need to be considered.
\end{abstract}

Keywords-component; waste-to-energy; municipal solid waste management; renewable technology

\section{INTRODUCTION}

By Thailand's Economic Growth, fast industrial expansion and rapid growth in population, energy consumption is becoming much more serious problems. Energy problem is one of the most important issues seeming endless and continually affects all human beings directly. Whereas the price of crude oil in the world market has been increased from time to time and the quantity of crude oil available is decreasing and shortage of fuel oils in Thailand, therefore, it is essential to urgently seek for some substitute resources. Governmental of Thailand has set renewable energy as the national agenda. It promotes production and utilization of renewable energy by providing incentives. MSWM may result in the solution of this problem by conversion of WtE. Currently, there are $5 \mathrm{WtE}$ technologies being employed in Thailand. The 5 types of technology are incineration, refuse derived fuel (RDF), anaerobic digestion, pyrolysis and gasification, and landfill gas recovery. All the methods mentioned will reduce the quantity of final waste into manageable amount as well as producing products that are environmental friendly. The purpose of this paper is to provide an overview the status of WtE in Thailand. In addition to that, the paper also summarizes national waste management policy as well as WtE policy to ensure that valuable resources can be separated before entering waste streams.

\section{NATIONAL ENERGy Policies IN Thailand}

The following national energy policy and Alternative Energy Development Plan (AEDP 2012 - 2021) have been approved by the Department of Alternative Energy Development and Efficiency, Ministry of Energy on 30 November 2011 as shown in Figure 1. Thailand's Ministry of Energy estimates that the potential of power generation in Thailand from biomass, biogas, and MSW is 4,390 MW. Other sources with good potential are solar and wind is 3,200 MW. There is a potential to generate another 1,608 MW of power from hydro power. In this viewing, $\mathrm{WtE}$ is one form of national energy policy. Therefore it is in the fourth rank of the national energy policy and development plan.

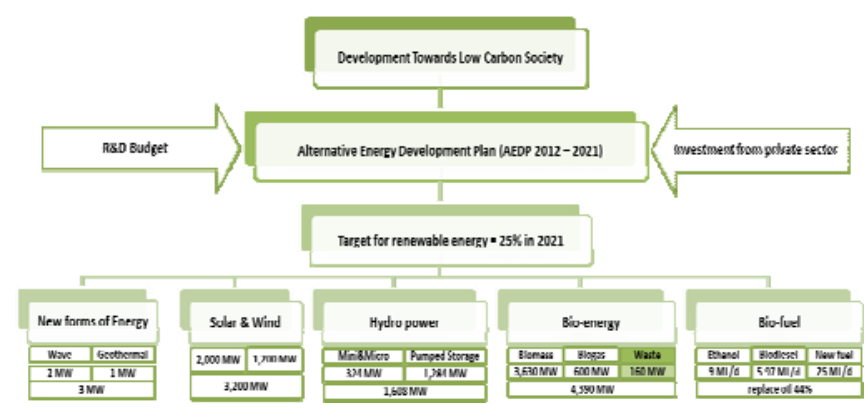

FIGURE I. ALTERNATIVE ENERGY DEVELOPMENT PLAN (AEDP 2012 - 2021) 10 YEARS IN THAILAND.

\section{CONVERSION OF SOLID WTE IN THAILAND}

Technology of solid wastes to energy in Thailand consists of 6 technologies which are incineration, refuse derived fuel (RDF), biogas production by anaerobic digestion, pyrolysis, gasification, and landfill gas recovery. Each type is suitable for different area, depending on various factors including quantity, component and separation practice of solid wastes, number of staff, investment cost, operation cost, land requirement, local potentiality, etc. This section provides an overview of the conversion of WtE such as heat, steam, gases, and oils. Furthermore this section also compares the different types of WtE technologies as shows in Table 1. 


\section{A. Incineration with Energy Recovery}

Incineration, also referred to as combustion, is a specialized process that involves the burning of combustible materials in any state to form gases and residue. The basic elements of an incinerator include a feed system, combustion chamber, exhaust gas system and a residue disposal system; whereas modern incinerators use continuous feed systems and moving grates within a primary combustion chamber lined with heat resistant materials. The waste must be mixed, dried, and then heated, all for specific amounts of time and at controlled temperatures. Different types of incinerators are in common use such as mass-fired combustors, refuse derived fuel combustors, and industrial incinerators [1]. Currently there were 3 incinerations for communities' wastes in Thailand namely Phuket province (250 ton/day), Samui Island (75 ton/day), and Lamphun province (10 ton/day).

\section{B. Refuse Derived Fuel (RDF)}

RDF is a fuel produced through the management of MSW. RDF can also be named as solid recovered fuel or specified recovered fuel (SRF). The residual wastes after separate collection of recoverable materials are treated through mechanical reprocessing and fractionation. The RDF obtained from this process is traded and co-burnt in installations for power generation or in a manufacturing process where heat is required such as co-combustion in coal fired boilers, coincineration in cement kilns, and co-gasification with coal or biomass. Presently, there is RDF production plant in Thailand by using Mechanical Biological Treatment (MBT) in Phitsanulok municipality [2]. This project has been carried out by the Municipality of Phitsanulok and the German Agency for Technical Cooperation (GTZ). A pilot facility was envisaged to treat $50 \%$ of incoming waste in the landfill [3]. In addition, there is another RDF production plant in Nakhon Ratchasima City Municipality which is suspended because the operation cost and the commercial use of RDF has yet to extensively occur.

\section{Biogas Production by Anaerobic Digestion}

The organic fraction of the waste is mashed and placed in a contained digester to decay by without oxygen. Primarily carbon dioxide and methane is call biogas, but also small amounts of hydrogen sulfide, ammonia, and other compounds are produced by this process. Besides, the solid material drawn from the anaerobic digester is called, or effluent. It is rich in nutrients and is an excellent soil conditioner. In Thailand, the purpose of anaerobic digesters is to utilize the biogas produced as a source of fuel for generators and the sludge byproduct as a fertilizer.

\section{Pyrolysis}

Pyrolysis is chemical decomposition by heat in the absence of oxygen converting carbonaceous material into fuel gas that can be used as a substitute for natural gas. The pyrolysis process, like incineration, can be continuous or batch fed, producing char, pyrolysis oils, and gases. The process is conducted at $815^{\circ} \mathrm{C}$, most commonly in what is called a fluidized bed. Cellulose molecules within the municipal waste dissociate instead of burning, due to the absence of oxygen.
The fragments of the dissociated molecule form methane, carbon dioxide, hydrogen, carbon monoxide, and water [4]. Currently there is pyrolysis for communities' wastes in Thailand: Warin Chamrap, Ubon Ratchathani Province (6 ton/day of plastic waste generated 4,500 L/day of fuel oil).

\section{E. Gasification}

Gasification is a modification of pyrolysis in that a limited quantity of oxygen is introduced, and the resulting oxidation produces enough heat to make the process self-sustaining. Gasification occurs at very high temperatures and involves the partial combustion of a carbonaceous fuel (combustible, putrescible, and plastic fractions of the waste), which produces combustible fuel gas rich in carbon monoxide, hydrogen and some saturated hydrocarbons (mostly methane) [5].

\section{F. Landfill Gas Recovery}

Generation of methane from a sanitary landfill is similar to anaerobic digestion, but without operational control of the process. The waste is simply left as is with no efforts made to increase gas production; gas is simply captured as it is generated. Landfill gas typically consists of $50-60 \%$ methane, $40-50 \%$ carbon dioxide, and trace levels of other gases. Typical landfill gas has an energy equivalent to about half that of natural gas [6].

\section{SUMMARY}

It is clear that no one technology of WtE in Thailand can deal with all materials in an environmentally sustainable way. A suitable approach in converting the MSW into energy should be an integrated approach that could deliver both environmental and economic sustainability. With increasing environmental concerns, the $\mathrm{WtE}$ technologies have a potential to maximize the useable waste materials as well as reduction of GHG emissions. Waste in Thailand is very suitable for converting WtE with suitable technologies and reducing the disposal cost based on the amount of MSW generated such as incineration, refuse derived fuel (RDF), anaerobic digestion, pyrolysis and gasification, and landfill gas recovery.

\section{ACKNOWLEDGMENT}

The authors would like to thank the Joint Graduate School of Energy and Environment (JGEE) and Thammasat University (TU) Research Fund for financially supported.

\section{REFERENCES}

[1] Salvato, J.A., N.L. Nemerow, and F.J. Agardy, Environmental Engineering2003: John Wiley \& Sons.

[2] phitsanulokhotnews. MOU waste as fuel for cement industry. 2013; Available from: http://www.phitsanulokhotnews.com/32262.

[3] University, E.R.C.E.N., Characteristics of Solid Waste after Mechanica Biological Treatment (MBT), 2006.

[4] Scheirs, J. and W. Kaminsky, Feedstock recycling and pyrolysis of waste plastics: converting waste plastics into diesel and other fuels2006: J. Wiley \& Sons.

[5] Heermann, C., et al., Pyrolysis \& Gasification of Waste: Technologies \& processes2000: Juniper Consultancy Services.

[6] Rajaram, V., F.Z. Siddiqui, and M.E. Khan, From Landfill Gas to Energy: Technologies and Challenges2011: CRC/Balkema. 
[7] Corporation, F. Energy/Resource Conservation. 2013; Available from: http://www.fmc.com/corporateresponsibility/HealthSafetyEnvironment/

EnergyResourceConservation.aspx.

TABLE I COMPARISON OF DIFFERENT TYPES OF WTE TECHNOLOGY.

\begin{tabular}{|c|c|c|c|c|c|c|}
\hline Attributes & Incineration & RDF & Anaerobic digestion & Pyrolysis & Gasification & Landfill gas \\
\hline Methods & $\begin{array}{l}\text { Thermochem } \\
\text { ical }\end{array}$ & Thermochemical & Biochemical & Thermochemical & Thermochemical & Biochemical \\
\hline $\begin{array}{l}\text { Suitable waste } \\
\text { characteristics }\end{array}$ & $\begin{array}{l}\text { Sorted } \\
\text { combustible } \\
\text { waste }\end{array}$ & $\begin{array}{l}\text { Sorted } \\
\text { combustible } \\
\text { waste }\end{array}$ & $\begin{array}{l}\text { Sorted organic waste: } \\
\text { suitable for either wet or } \\
\text { dry waste depending on } \\
\text { type of AD system }\end{array}$ & $\begin{array}{l}\text { Sorted } \\
\text { heterogeneous MSW }\end{array}$ & $\begin{array}{l}\text { Sorted organic } \\
\text { (combustible, } \\
\text { putrescible, and plastic } \\
\text { fractions of the waste) }\end{array}$ & Unsorted waste \\
\hline Description & $\begin{array}{l}\text { Waste is } \\
\text { broken down } \\
\text { to produce } \\
\text { heat. }\end{array}$ & $\begin{array}{l}\text { Waste is broken } \\
\text { down to produce } \\
\text { the high calorific } \\
\text { fraction. }\end{array}$ & $\begin{array}{l}\text { Organic biodegradable } \\
\text { waste broken down } \\
\text { without oxygen } \\
\text { (anaerobic) to produce } \\
\text { methane gas, carbon } \\
\text { dioxide, water, and } \\
\text { digestive (which is } \\
\text { composted). Can be wet } \\
\text { or dry. }\end{array}$ & $\begin{array}{l}\text { Waste is broken } \\
\text { down by heat in the } \\
\text { absence of oxygen to } \\
\text { produce fuel gas. }\end{array}$ & $\begin{array}{l}\text { Waste is broken down } \\
\text { by heat with a limited } \\
\text { quantity of oxygen to } \\
\text { produce fuel gas. }\end{array}$ & $\begin{array}{l}\text { Waste placed in a } \\
\text { landfill breaks down } \\
\text { over time due to } \\
\text { biological, physical, } \\
\text { and chemical } \\
\text { processes emerging } \\
\text { technologies, such as } \\
\text { bioreactor landfills, } \\
\text { may offer more } \\
\text { sustainable } \\
\text { approaches to landfill } \\
\text { disposal of wastes. }\end{array}$ \\
\hline Energy form & Heat & Solid fuel & Fuel gas & $\begin{array}{l}\text { Char, pyrolysis oil, } \\
\text { and gases }\end{array}$ & Syngas & LFG \\
\hline $\begin{array}{l}\text { General } \\
\text { performance }\end{array}$ & $\begin{array}{l}\text { Thermal } \\
\text { treatment can } \\
\text { divert } 70 \text { per } \\
\text { cent of waste } \\
\text { from landfill }\end{array}$ & $\begin{array}{l}\text { Can divert most } \\
\text { combustible of } \\
\text { waste from } \\
\text { landfill }\end{array}$ & $\begin{array}{l}\text { Can divert all or most } \\
\text { organic and biodegradable } \\
\text { products (food, yard } \\
\text { waste, some papers) }\end{array}$ & $\begin{array}{l}\text { Can divert most a } \\
\text { mixed } \\
\text { (heterogeneous) } \\
\text { waste stream from } \\
\text { landfill }\end{array}$ & $\begin{array}{l}\text { Can divert most } \\
\text { combustible organic of } \\
\text { waste from landfill }\end{array}$ & $\begin{array}{l}\text { A wide range of } \\
\text { performance is } \\
\text { available. Individual } \\
\text { facilities are } \\
\text { custom designed and } \\
\text { constructed to meet } \\
\text { desired waste } \\
\text { management } \\
\text { objectives }\end{array}$ \\
\hline $\begin{array}{l}\text { Community } \\
\text { characteristics }\end{array}$ & $\begin{array}{l}\text { Thermal } \\
\text { treatment is a } \\
\text { high-tech } \\
\text { system that } \\
\text { requires } \\
\text { skilled } \\
\text { technical } \\
\text { operators. } \\
\text { Depending } \\
\text { upon the } \\
\text { specific } \\
\text { technology, it } \\
\text { is suitable for } \\
\text { communities } \\
\text { ranging from } \\
\text { small villages } \\
\text { to large urban }\end{array}$ & $\begin{array}{l}\text { RDF systems } \\
\text { treat waste is a } \\
\text { high-tech system } \\
\text { that requires } \\
\text { skilled technical } \\
\text { operators. } \\
\text { Depending upon } \\
\text { the specific } \\
\text { technology, it is } \\
\text { suitable for } \\
\text { communities } \\
\text { ranging from } \\
\text { large urban }\end{array}$ & $\begin{array}{l}\text { Anaerobic digestion is a } \\
\text { high-tech system that } \\
\text { requires skilled technical } \\
\text { operators. It is most suited } \\
\text { to reasonably large urban } \\
\text { areas to justify the } \\
\text { construction of the system }\end{array}$ & $\begin{array}{l}\text { Pyrolysis of waste is } \\
\text { a high-tech system } \\
\text { that requires skilled } \\
\text { technical operators. } \\
\text { Depending upon the } \\
\text { specific technology, } \\
\text { it is suitable for } \\
\text { communities ranging } \\
\text { from large urban }\end{array}$ & $\begin{array}{l}\text { Gasification of waste } \\
\text { is a high-tech system } \\
\text { that requires skilled } \\
\text { technical operators. } \\
\text { Depending upon the } \\
\text { specific technology, it } \\
\text { is suitable for } \\
\text { communities ranging } \\
\text { from large urban }\end{array}$ & $\begin{array}{l}\text { Landfill disposal of } \\
\text { waste is a necessary } \\
\text { element of an } \\
\text { integrated } \\
\text { approach to waste } \\
\text { management in all } \\
\text { Thailand } \\
\text { communities }\end{array}$ \\
\hline Costs & $\begin{array}{l}\text { Costs will } \\
\text { vary } \\
\text { depending } \\
\text { upon the } \\
\text { specific } \\
\text { thermal } \\
\text { technology } \\
\text { used and the } \\
\text { operating } \\
\text { capacity } \\
\text { required }\end{array}$ & $\begin{array}{l}\text { Costs will vary } \\
\text { depending upon } \\
\text { the technology } \\
\text { used and } \\
\text { the operating } \\
\text { capacity required }\end{array}$ & $\begin{array}{l}\text { Costs require a plant size. } \\
\text { Costs decrease Greatest } \\
\text { economies of scale at } \\
100,000 \text { tons/year }\end{array}$ & $\begin{array}{l}\text { Costs will vary } \\
\text { depending upon the } \\
\text { technology used and } \\
\text { the operating } \\
\text { capacity required }\end{array}$ & $\begin{array}{l}\text { Costs will vary } \\
\text { depending upon the } \\
\text { technology used and } \\
\text { the operating capacity } \\
\text { required }\end{array}$ & $\begin{array}{l}\text { Costs can vary } \\
\text { significantly } \\
\text { depending upon } \\
\text { waste input rates and } \\
\text { characteristics, site- } \\
\text { specific conditions, } \\
\text { regulatory } \\
\text { requirements, } \\
\text { size of facilities and } \\
\text { economies of scale, } \\
\text { design and } \\
\text { construction } \\
\text { requirements, and } \\
\text { local/regional } \\
\text { competition from } \\
\text { other landfills }\end{array}$ \\
\hline
\end{tabular}




\begin{tabular}{|c|c|c|c|c|c|c|}
\hline $\begin{array}{l}\text { Factors that } \\
\text { influenced } \\
\text { acquisition }\end{array}$ & $\begin{array}{l}\text { The } \\
\text { availability } \\
\text { of local } \\
\text { energy } \\
\text { markets is a } \\
\text { critical factor } \\
\text { in the } \\
\text { decision }\end{array}$ & $\begin{array}{l}\text { The availability } \\
\text { of local energy } \\
\text { markets is a } \\
\text { critical factor in } \\
\text { the decision }\end{array}$ & $\begin{array}{l}\text { Availability of local } \\
\text { energy }\end{array}$ & $\begin{array}{l}\text { The availability of } \\
\text { local energy markets } \\
\text { is a critical factor in } \\
\text { the decision }\end{array}$ & $\begin{array}{l}\text { The availability of } \\
\text { local energy markets is } \\
\text { a critical factor in the } \\
\text { decision }\end{array}$ & $\begin{array}{l}\text { Low costs relative to } \\
\text { other options. } \\
\text { Limitations on } \\
\text { availability of } \\
\text { other alternatives }\end{array}$ \\
\hline $\begin{array}{l}\text { Possible } \\
\text { environmental } \\
\text { impact }\end{array}$ & $\begin{array}{l}\text { air pollution, } \\
\text { particulate } \\
\text { matter, solid } \\
\text { residue and } \\
\text { wastewater }\end{array}$ & $\begin{array}{l}\text { soot or dust and } \\
\text { air pollution } \\
\text { generated from } \\
\text { fuel burning }\end{array}$ & $\begin{array}{l}\text { odor and disease } \\
\text { generated from solid } \\
\text { wastes fermentation }\end{array}$ & $\begin{array}{l}\text { gas or vapor from } \\
\text { combustion, carbon } \\
\text { black, solid residue } \\
\text { from burning and } \\
\text { wastewater }\end{array}$ & $\begin{array}{l}\text { gas or vapor from } \\
\text { combustion, carbon } \\
\text { black, solid residue } \\
\text { from burning and } \\
\text { wastewater }\end{array}$ & $\begin{array}{l}\text { Methane gas that is } \\
\text { risk to explosion }\end{array}$ \\
\hline $\begin{array}{l}\text { Energy } \\
\text { implication }\end{array}$ & $\begin{array}{l}\text { Thermal } \\
\text { energy and } \\
\text { convert to } \\
\text { electrical } \\
\text { energy } \\
\end{array}$ & $\begin{array}{l}\text { Thermal energy } \\
\text { and convert to } \\
\text { electrical energy }\end{array}$ & Net energy generator & $\begin{array}{l}\text { Energy for } \\
\text { conventional engines } \\
\text { and boilers }\end{array}$ & $\begin{array}{l}\text { Energy for making } \\
\text { products; Methanol, } \\
\text { Ammonia, Diesel fuel }\end{array}$ & Net energy generator \\
\hline
\end{tabular}

